Lyuboslav Lyubenov, $P h D$ candidate

University of Ruse, Bulgaria

\title{
THE RIGHT OF THE ACCUSED PERSONS OF ACCESS TO A LAWYER IN PRELIMINARY CRIMINAL PROCEEDINGS ACCORDING TO THE CRIMINAL PROCEDURE CODE OF REPUBLIC OF BULGARIA IN REFERENCE TO DIRECTIVE 2013/48/EU
}

\section{APSŪDZĒTO PERSONU TIESİBAS UZ ADVOKĀTA PALİDZĪBU SĀKOTNĒJĀ KRIMINĀLPROCESĀ SASKAN̦Ā AR BULGĀRIJAS REPUBLIKAS KRIMINĀLPROCESA KODEKSU, ATSAUCOTIES UZ DIREKTĪVU 2013/48/ES}

\begin{abstract}
Kopsavilkums
2019. gadā tika pieņemti svarīgi grozījumi Bulgārijas Republikas Kriminālprocesa kodeksā par Eiropas Parlamenta un Padomes 2013. gada 22. oktobra Direktīvu 2013/48/ES par tiesībām uz advokāta palīdzību kriminālprocesā un Eiropas apcietināšanas ordera procesā, par tiesībām uz to, ka pēc brīvỉbas atņemšanas informē trešo personu, un par tiesībām, kamēr atñemta brīvība, sazināties ar trešajām personām un konsulārajām iestādēm. Direktīvā 2013/48/ES ir noteikti minimālie noteikumi par tiesībām uz advokāta palīdzību kriminālprocesā un Eiropas apcietināšanas ordera izpildes procesā. Direktīva palīdz īstenot Eiropas Savienības Pamattiesību hartu un Eiropas Cilvēktiesību konvenciju. Kriminālprocesa kodeksa grozījumi attiecas uz pieejamās vispārējās informācijas sniegšanu, lai atvieglotu apsūdzētajai personai advokāta palīdzības saņemšanu, kā arī aizsargātu apsūdzētās personas tiesības brīvi sazināties un konsultēties ar advokātu un saņemt tā palīdzību; tikties ar vinuu, saṇemt konsultācijas un citu juridisko palīdzību arī pirms tiesas sēdes un tās laikā, kā arī atvieglotu citas procesuālas darbības, kurās iesaistīit apsūdzētie utt. Šajā dokumentā uzmanība tiek pievērsta tiesībām uz advokāta palīdzību kriminālprocesā - tiek vērtēts, kā Direktīvas 2013/48/ES 6. panta 3. punkta transponēšana ietekmē valsts tiesību aktus par apsūdzēto personu tiesībām uz aizstāvību.
\end{abstract}

Atslēgvārdi: ES tiesības, kriminālprocesa tiesības, tiesības uz palīdzību

\section{Summary}

In 2019, important amendments were adopted to Criminal Procedure Code of Republic of Bulgaria concerning the full transposition of Directive 2013/48/EU of the European Parliament and of the Council of 22 October 2013 on the right of access to a lawyer in criminal proceedings and in European arrest warrant proceedings, and on the right to have a third party informed upon deprivation of liberty and to communicate with third persons and with consular authorities while deprived of liberty. Directive 2013/48/EU establishes the minimum rules on the right of access to lawyer in the criminal proceedings and in the proceedings for the execution of the European arrest warrant. The Directive contributes 
to the implementation of the Charter of Fundamental Rights of the European Union, and the European Convention on Human Rights. The amendments in the Criminal Procedure Code concern providing general information available to facilitate the obtaining of a lawyer by accused persons; the right of the accused person freely to contact, consult and assist by a lawyer; meet with him, receive advice and other legal assistance, including before and during the hearing, and any other procedural action involving the accused, etc. The focus of this paper is on the right of access to a lawyer in criminal proceedings - how the transposition of the Directive 2013/48/EU affects the national regulation concerning the right of defense of the accused persons.

Keywords: EU law, criminal procedure law, right to access

\section{Introduction}

Directive 2013/48/EU of 22 October 2013 is a further development of the principle of fair justice, incorporated in the European Convention of Human Rights (ECHR) and International Pact for Civil and Political Rights (IPCPR), requiring higher due care from the side of the state as regards the personality of the suspected or accused person who is in a potentially weak position. In pursuance of this fundamental requirement, the European legislator, by means of the Directive, established the minimum rules regarding the right of suspected and accused persons in criminal proceedings and persons to whom proceedings under Framework Decision 2002/584/ JHA on access to a lawyer and on notification to a third person upon detention and to liaise with third parties and consular authorities during their detention. According to Art. 2 of the Directive, these minimum and common rules should apply as a rule in the judicial proceedings and, exceptionally, in the pre-litigation phase - "... fully apply where the suspect or accused person is deprived of liberty, irrespective of the stage of the criminal proceedings." Since the current publication is thematically limited, an attempt is made to examine only the right of the accused to access a lawyer in the preliminary proceedings. The analysis below aims to identify the actual factual needs of the accused by qualified legal aid in the pre-trial phase and the extent of their regulatory reporting in the Directive 2013/48/EC (hereinafter referred to as the Directive) and in the Criminal Procedural Code of Republic of Bulgaria (CPC), on the one hand, and, on the other, to verify and refine the synchronization between the provisions of the $\mathrm{CPC}$ and the Directive in the part regulating the right of access to a lawyer.

\section{The right of the accused persons of access to a lawyer in preliminary criminal proceedings according to the Criminal Procedure Code of Republic of Bulgaria}

According to Art. 97, para. 1 of the Bulgarian Criminal Procedure Code, the defender may be involved in the criminal proceedings, including in the preliminary proceedings, from the time of the person's detention or the acquittal in the procedural quality of the accused. Paragraph 2 of the same article stipulates that the pre-trial body is required to 
explain to the accused that he is entitled to a legal counsel and to enable him to contact him immediately. In this sense, Art. 97 of the CPC fully complies with Art. 2 of the Directive, stating that the accused or suspect may acquire rights from the Directive at all stages of the trial if detained. Moreover, Art. 94, item 6 of the $\mathrm{CPC}$ requires that the person to whom a request for detention is required to use mandatory counselling services. Careful analysis of both Art. 97 of the CPC and Art. 2 of the Directive, in our opinion, reveals a general weakness. The exact wording of Article 2 of the Directive says: "In any event, this Directive shall fully apply where the suspect or accused person is deprived of liberty, irrespective of the stage of the criminal proceedings." Therefore, in order to apply the Directive, a necessary precondition is that an accused or a suspect is arrested. However, the acquisition of the procedural status of an accused or detained is linked to the proper performance of certain procedural obligations on the part of the state. By virtue of the Directive itself, the person concerned should be informed by the competent authorities by formal notice or otherwise that he is suspected or accused of committing a particular offense. Therefore, the actual needs of protection must be taken into account, including access to a lawyer. A person may be treated by the state in fact as an accused or a suspect and require a legal assistance from that point of view, even if he is not formally charged as a defendant or suspect with a special act or message. In these cases, the person may be detained, even if he is actually investigated in the absence of an opportunity to have a lawyer. In other words, it is not clear why the European legislator grants the right to effective access to a lawyer not from the moment when a person is detained (other than the cases referred to in para. 20 of the Preamble of the Directive), but only when that person is detained with acquiring the status of accused or suspect. At the same time, according to Art. 3 of the Directive, he also allows the latter to apply "...to persons other than suspects or accused persons who, in the course of questioning by the police or by another law enforcement authority, become suspects or accused persons." The last hypothesis, however, marks the possibility, in the course of an investigative action such as the interrogation, that a person may "turn" from a witness into a factually suspected or accused person. However, the problem here stems from the complete absence of a guiding objective criterion to determine the moment in which it can be maintained that a person has become from an examinant to a suspect or accused. This moment de lege lata remains entirely in the discretion of the interrogation officers. Moreover, no explicit obligation for national law enforcement authorities exists to monitor the actual occurrence of a suspect or accused in the criminal process, and to treat the lack of access to a lawyer from that very moment as a violation of the rights to defense. To a certain extent and within reason, as in a number of national legislations, including the Bulgarian right to a defense counsel, a part of the right of defense arises and attaches to a particular person only when he acquires an explicit and formal procedural status of the accused. In order to avoid this contradiction, the right of access to a lawyer in the pre-trial phase of the trial should not be made dependent on the strict formalization of the accusation. This consideration is valid, because the admission of a lawyer in the process does not, as a rule, contradict and exclude the possibility for the state to reach the objective truth of the case, and to conduct a lawful and correct criminal process, but on the contrary it reinforces the revelation of the truth, of the circumstances underlying the protection 
and guarantees the conduct of a fair trial within the meaning of Art. 6 of the ECHR. In general, it can be considered that "...the wider possibilities of the citizens who have intervened in the criminal process to defend their rights do not contradict the state interest, but they are determined and derive from it."' This conclusion is in the spirit of para. 52 of the Preamble to the Directive, proclaiming the need to implement its texts in accordance with the Convention. Moreover, in Strasbourg's case-law, it is particularly emphasized that the accusation should have a substantive rather than a formal significance. In the case of Yankov and others v. Bulgaria, it is assumed that "...the prominent place that the right to a fair trial takes in a democratic society implies rather a formal understanding than a "criminal charge"; it requires the Court to look beyond the apparent and examine the substance of the procedure in question." ${ }^{\text {"2 }}$ The human rights theory states that "... in practice, the person is the subject of an accusation when he is arrested for a crime; when informed of being charged with a crime; when a prior investigation has been initiated in a system of continental law and, although not under arrest, the complainant has formally learned of the investigation or is already affected by it; where the authorities investigating a customs offense require the person to provide evidence and when they freeze his bank account; or when the applicant's shop is closed while waiting for the outcome of the criminal proceedings." ${ }^{3}$ Considering, therefore, the autonomy of the Convention and the principle of proportionality in its interpretation, it can be concluded that in European theory and practice there is a desire for the right to a defense to be derived and made available not according to formal charges and formal recruitment accused by deliberate act, but depending on the actual involvement of a person by the actions of the state and his actual treatment as an accused or suspect. For this reason, de lege ferenda, the European legislator, in order to allow and ensure full, effective and adequate access to a lawyer, should proceed with the refinement of the legal framework in this part, not so much of the procedural status of the detainee as the type of his detention, actual length of detention and the objectives pursued with it. Regarding the Bulgarian regulation of detention, the CPC, as it was clear and above, has assumed the understanding that the defense counsel, including a lawyer as a person indicating qualified legal aid, may participate in the preliminary criminal proceedings from the time of the detention or involvement of a person as an accused. In connection with the clarification of the use in Art. 97 of the CPC, 'detention' in the most recent Bulgarian theory, it is assumed that this is the moment when a person is detained by the prosecutor on the grounds of Art. 64, para. 2 of the Criminal Procedure Code or the taking of a detention order 4 Not so thorough analysis of Art. 64, para. 2 of the CPC leads to the conclusion that in this case the prosecutor can keep the accused for 72 hours in order to bring him to

Павлов С. Наказателен процес на Република Бъмгария - обща част. София: Сиби, 1996 г., р. 90.

Available at: https://hudoc.echr.coe.int/eng\#\{,fulltext“:[„》“CASE\%20OF\%20YANKOV\%20AND\%20OTHERS\%20v.\%20BULGABUL【“"],"documentcollectionid2“:[„,GRANDCHAMBER““'CHAMB ER"]\} [last viewed June 19, 2019].

3 Харис A., O` Бойл М., Уорбрик Е., Бейтс К., Бъкми К. Право на Европейската конвенция за защита правата на човека. София: Сиела, 2015 г., рр. 444-445.

4 Чинова М. Аосъдебното производство по ПНК - теория и практика. София: Сиела, 2013 г., p. 187. 
court. The Bulgarian legislature itself uses the phrase "the appearance of the accused before the court" is ensured by the prosecutor. That is why the reasoning of the legislator in Art. 97 of the CPC to make alternative differentiation - namely, the participation of a counsel should be allowed from the moment of detention or from the recourse of a person as an accused, in both cases, the arrested accused is detained. Even in para. 2 of Art. 97 of the CPC, it is stated that the pre-trial according to the general procedure for attracting an accused, prescribed in Article 219 (1) of the CPC: "Where sufficient evidence is collected for the guilt of a certain individual in the perpetration of a publicly actionable criminal offence, and none of the grounds for terminating criminal proceedings are present, the investigative body shall report to the prosecutor and issue a decree to constitute the person as accused party." That is, an accused is attracted when sufficient evidence is gathered about the guilt of a person in committing a certain crime. However, gathering evidence against a person is always related to an investigation against him. There is neither life logical nor legal logical reason for a person to have access to a lawyer until after the investigation has been completed and his involvement as an accused, and he is not in the course of the investigation itself. Indeed, the legislator himself states in Art. 55 para. 1 of the CPC that the accused has the right to a defense counsel, therefore, the right of defense will arise with the emergence of the procedural status of the accused, that is, after collecting sufficient evidence against a person in question. It is unjustifiable that access to a lawyer is ensured only when the accused is detained. This conclusion is supported also by the one formed under Art. 5 of the ECHR case-law of the Court of Human Rights. The first arrest for the purposes of the Convention is also the arrest of a person against whom there is only sufficient factual data or information, but not evidence that would convince the objective observer that he or she has committed a particular offense ${ }^{5}$. Secondly, according to Article 5, par. 4 of the ECHR, every arrested and imprisoned person has a right to appeal the lawfulness of his detention to a court who can, in the short term, render his release. In relation to that control, it is claimed that "...judicial review is not an appeal, but it must be duly considered the procedural and substantive legal conditions essential to the lawfulness of the deprivation of liberty", "...the supervisory authority merely examines the charges against the applicant and does not examine the specific facts as to the justification of the charges against him for the purpose of granting the release if it cannot be shown that the condition of reasonable suspicion is fulfilled." ${ }^{\prime}$ Hence, a person can be only reasonably suspected but not accused to instigate immediately revision of his detention before a court. The Bulgarian CPC does not know de lege lata the figure of the suspect. Moreover, in the case of Art. 64, para. 2 of the Criminal Procedure Code provides detention for a period of 72 hours to ensure the appearance of the accused in court for the purpose of taking a measure of remand. Within this time, in the CPC the legislator did not allow the detainee to make a revision of his detention before a court, something which contradicts to both - the Directive and the Convention. Thirdly, an account must be taken of the total length of detention under the Convention - the maximum period that may

Available at: https://hudoc.echr.coe.int/eng\#\{„fulltext“:[,„fox“],"documentcollectionid2“:[„„GRAND CHAMBER",'CHAMBER"] \} [last viewed June 19, 2019].

6 Харис А., О’ Бойл М., Уорбрик Е., Бейтс К., Бъкли К., pp. 414-415. 
expire before a person receives a request for control in the court is four days ${ }^{7}$ and the detention by the prosecutor under the Bulgarian Criminal Procedure Code remains within the only one day, but without a control procedure. Here is the time to note that regarding the police detention under Art. 72 of the Ministry of Interior Act, the Bulgarian regulation of 2019 is fully synchronized with the requirements of the Convention. Article 72, para. 4 of the Bulgarian Ministry of Interior Act states: “...The detainee has the right to appeal the lawfulness of the detention to the district court at the head of the body. The court decides on the appeal immediately and its decision is subject to a cassation control under the Administrative Procedure Code before the respective administrative court." This amendment also achieves the requirement in the preamble of the Directive to secure the detained higher security level of police arbitrariness. With this model de lege ferenda, it is advisable to strengthen and extend the scope of the judicial review and prosecutorial detention. Full judicial control was introduced over detention in custody as a measure of remand - Art. 65 CPC.

\section{The right to of the accused persons of access to a lawyer in the context of Directive 2013/48/EU}

The Directive is based on the understanding that when a person, in the course of his interview, turns from a witness to a suspect or accused, the same should use all the rights under the Directive, that is to say, the right to a lawyer's access to a lawyer in a timely and effective manner. According to par. 21 of the Preamble: "...Where, in the course of such questioning, a person other than a suspect or accused person becomes a suspect or accused person, questioning should be suspended immediately. However, questioning may be continued if the person concerned has been made aware that he or she is a suspect or accused person and is able to fully exercise the rights provided for in this Directive." This standard protects individuals whose activity is clarified through interrogation of testimony against themselves and allows them to remain in silence. The aforementioned understanding has not yet found a normative expression in the Bulgarian CPC. The matter governing the hearing of a witness in pre-trial proceedings (Articles 139-141a of the Criminal Procedure Code) does not include the immediate termination of the interrogation in the event that the witness is treated as an offender in committing the offense for which he is being questioned. This is a serious shortcoming because it allows the bodies conducting the interrogation, especially in the process of the preliminary check under Art. 145 of the Judiciary System Act to obtain certain information and confessions, which at a later stage in the process could be used to substantiate the indictment in the absence of the requirement of equality of arms and the prohibition of self-examination ${ }^{8}$ within the meaning of Art. 6 of the ECHR. For

МакбрайА Аж. Правата на човека и наказателния процес - практиката на Европейския съА по правата на човека. Страсбург: Съвет на Европа, 2012 г., рр. 50-51.

8 Правото на справедлив съдебен процес. Ръководство по чмен 6 на Европейската конвенция за правата на човека. Council of Europe/European Court of Human Rights. София: Сиби, 2016 г., pp. 143-144. 
this reason, a legislative change is needed in the opposite sense. The replacement of procedural probative activity with the means of a factual investigation is nothing more than infiltrating the 'virus' at the investigative point of view because the preliminary investigation can only fulfil its tasks if it obeys the procedural forms provided by the Criminal Procedure Code?

According to Art. 3 of the Directive, the right of access to a lawyer consists of the following: the right of the accused or the suspect to meet alone and to contact the lawyer representing them; the right of the accused or the suspect to request the presence of his attorney while their inquiries are taking place; the right of the accused or the suspected presence of their attorney in the course of action to collect evidence when these are provided for in national law and where the suspected or accused person is obliged or permitted to be present when the relevant investigative measure. In specifying these actions, the European legislator has drawn: recognition, eye-rate and restoration of the crime scene. As far as the first of the listed rights of the accused is concerned, namely the right to meet himself with his defense counsel, compliance with the Directive has been achieved in the Bulgarian Criminal Procedure Code by the explicit incorporation in Art. 99, para. 1 of the Code of the Defender's Rights to meet in private with the accused. For a fuller provision of this right in the pre-trial phase, it is advisable in the future for the legislator to pronounce specifically in Art. 55 of the Criminal Procedure Code and the right of the accused to meet in private with the lawyer representing him, as de lege lata the defense counsel is the exclusive holder of this subjective right, and, hence, the same will be exercised wholly depending on his will for that. Concerning the right of the accused to require the presence of his attorney during his interrogation in Art. 138 of the Criminal Procedure Code, which regulates the interrogation of the accused, there is no mention in this regard in particular. However, it must be assumed that this right is ensured in the preliminary proceedings, yet, by analogy with that provided in Art. 99, para. 1 of CPC, the right of the defense counsel to participate in all the investigative activities that are carried out with the participation of the accused, including those implemented during the conduct of the interrogation of the accused as a measure of inquiry with a purpose of collecting vindictive evidence.

An interesting view concerns the last of the content of the right of access to a lawyer: to be able to participate in eyewitness, recognition, and investigative experiment. In the Bulgarian procedural law, it is not explicitly stated in the settlement of the abovementioned investigative actions that the accused would have a right to appear with a defense counsel either in the process implementing these investigative actions by the competent authorities, or in the normative of the eye rate - Art. 143 CPC, or in recognition - Art. 169-171 of the CPC, or in the Investigative Experiment - Art. 166168 CPC. However, the possibility for the accused to stand with a defense counsel when undertaking any of these listed actions is understood and deduced from the general text of Art. 55 of the CPC, where it is deliberately stipulated that "The accused

9 Съмов И. Съдът - разслеАващ орган, обвинител или арбитър в наказателното производство. София: Фенея, 2002 г., рр. 86-87. 
party shall have the right his/her defences counsel to take part when investigative actions are taken, as well as in other procedural action requiring the attendance thereof, unless he has expressively made waiver of this particular right." It can be concluded that the content of the right of access to a lawyer under the Directive has been transposed into the Bulgarian Criminal Procedure Code primarily through the general procedural provisions contained in the general part of the law.

For the sake of completeness, it is necessary to mention that, in exceptional circumstances and only in the pre-trial phase of the process, Member States may introduce a temporary derogation from the rights provided for in Art. 3 of the Directive. The derogation is admissible only if it is possible to infer from the facts of the case one of the following compelling reasons:

"... an urgent need to avert serious adverse consequences for the life, liberty or physical integrity of a person;"

"... immediate action by the investigating authorities is imperative to prevent substantial jeopardy to criminal proceedings." 10

The derogation is, therefore, inadmissible as a rule and exceptionally admissible for the reasons of preservation of the integrity of the person in the criminal process or of the possibility of revealing the objective truth in the case.

\section{Conclusions}

Finally, it should be pointed out that the most comprehensive implementation of the Directive in the Bulgarian positive law creates a real guarantee both for the welfare of the accused person or for the suspect, and for the conduct of democratic and fair pre-trial proceedings. A general recommendation to the European and Bulgarian legislators could be the need to legislate on the right to protection, in particular, the right of access to a lawyer to the actual needs of the suspect or accused. To that end, the moment of the right to defense should be rethought and bound by material instead of formal criteria for the formulation of the criminal charge. Last but not least, it should be added that the amendments to the Bulgarian Criminal Procedure Code from 2017 show some progress in ensuring a more complete and effective protection of the citizens involved in the criminal proceedings, however, in order to achieve the procedure entirely to Art. 6 of the ECHR, this process must continue to develop and gain profundity mainly through alignment of procedural defense capabilities with those of the accusation.

\section{ACKNOWLEDGEMENT}

The study was supported by contract of University of Ruse "Angel Kanchev", № BG05M2OP001- 2.009-0011-C01, "Support for the development of human resources

10 Available at: https://eur-lex.europa.eu/legal-content/BG/TXT/?uri=CELEX\%3A32013L0048 [last viewed June 19, 2019]. 
for research and innovation" at the University of Ruse "Angel Kanchev". The project is funded with support from the Operational Program "Science and Education for Smart Growth 2014-2020" financed by the European Social Fund of the European Union.

\section{BIBLIOGRAPHY}

1. МакбрайА Аж. Правата на човека и наказателния процес - практиката на Европейския съА по правата на човека. Страсбург: Съвет на Европа, 2012.

2. Павлов С. Наказателен процес на Република Бъмгария - обща част. София: Сиби, 1996.

3. Правото на справедлив съдебен процес. Ръководство по чиен 6 на Европейската конвенция за правата на човека. Съвет на Европа/Европейски съА за защита правата на човека. София: Сиби, 2016.

4. Съмов И. Съдът - разследващ орган, обвинител или арбитър в наказателното производство. София: Фенея, 2002.

5. Харис А., О’Бойл М., Уорбрик К., Бейтс Е., Бъкли К. Право на Европейската конвенция за защита правата на човека. София: Сиела, 2015.

6. Чинова М. Аосъдебното производство по ПНК - теория и практика. София: Сиела, 2013, p. 187.

\section{Normative acts}

7. Criminal procedure code of Republic of Bulgaria. Directive 2013/48/EU of the European Parliament and of the Council of 22 October 2013. Available at: https://eur-lex.europa.eu/ legal-content/EN/TXT/HTML/?uri=CELEX:32013L0048\&from=BG [last viewed June 19, 2019].

\section{Court practice}

8. Judgment of European Court of Human Rights, case No. 39084/97 Yankov v. Bulgaria.

9. Judgment of European Court of Human Rights, case No. 12383/86 Fox, Campbell and Hartley v. The United Kingdom. 